\title{
The effect of feeding broiler chicks during transportation on yolk sac, body weight and anti-IBDV level in blood
}

\author{
R.K. Pisarski ${ }^{1,3}$, I. Pijarska ${ }^{2}$ and H. Malec ${ }^{2}$ \\ ${ }^{1}$ Lublin Agriculture University, Institute of Animal Nutrition \\ Akademicka 13, 20-950 Lublin, Poland \\ ${ }^{2}$ Poultry Farm, Dębówka 1A, 05-533 Sobików, Poland
}

\begin{abstract}
Feeding chickens a commercial prestarter during a $20 \mathrm{~h}$ period of transportation from a hatchery had no significant effect on either the body weight of broilers reared until $336 \mathrm{~h}$ of age and the yolk sac weight and composition. In the yolk sac sampled after $72 \mathrm{~h}$ of rearing, a significant change in the fatty acid profile was noted. In the broilers given the prestarter, the share of SFA and PUFA was higher, whereas MUFA was lower, compared with chicks not fed a prestarter. Providing chicks with a commercial prestarter during transportation from a hatchery did not influence their immunity, expressed as the blood anti-IBDV level.
\end{abstract}

KEY WORDS: chicken, yolk sac, early nutrition, rearing, IBDV

\section{INTRODUCTION}

In the period between hatching and the first feeding, a chicks depends solely on yolk sac nutrients, which satisfy all of its maintenance requirements. A delay in feeding, however, is blamed for the metabolizing of specific yolk sac constituents (Cherian and Sim, 1997), which might result in lowered immunity of broilers as well as poorer utilization of residual yolk (Noy and Sklan, 2001). Furthermore, the delayed feeding might affect broiler productivity (Vieira and Moran, 1999), which highlights the strong need to find a practical solution to the identified problem.

Since the prolonged transportation of newly hatched chicks is the main reason for delayed feeding, the aim of the study was to evaluate the effects of providing

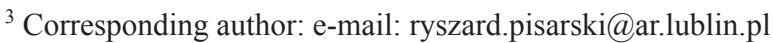


chicks with commercial prestarter during transportation on yolk sac weight and composition, broiler body weight, and anti-IBDV level.

\section{MATERIAL AND METHODS}

The studies were carried out on 300 one-day-old Cobb chicks. Immediately after hatching, 20 chicks (10 $\hat{\circ}$ and 10ㅇ) were sacrificed and blood and yolk sac samples were taken. The remaining chicks were divided at random into two groups: $\mathrm{F}+$ and $\mathrm{F}-(\mathrm{n}=140)$ and were transported for a $20 \mathrm{~h}$ period. During transportation the $\mathrm{F}+$ chicks were given $3 \mathrm{~g}$ per bird of commercial prestarter formula*. Directly after transportation both groups of broilers were placed in wire cages under the same environmental conditions and reared until 14 days of life. All of the broilers were given an identical commercial starter manufactured by Koudijs, containing, \%: crude protein 20.4, ether extract 4.4, crude fibre 3.2 and crude ash 5.3 (labelled as $6620 \mathrm{KBSF}$ ).

The effect of feeding chicks during transportation was assessed by the body weight and anti-IBDV level of 20 birds each group (10 $\overbrace{}^{-}$and 10ㅇ) aged 24, 72, 120,168 and $336 \mathrm{~h}$, as well as the weight and chemical composition of yolk sacs excised from 20 individuals at 24, 72, 120 and $168 \mathrm{~h}$ of life.

Crude protein and ether extract were determined by standard methods and the fatty acid profile (FA) by gas chromatography using a Varian CP-3800. The FA profile was expressed the sum of saturated (SFA), monounsaturated (MUFA) and polyunsaturated (PUFA) fatty acids. In blood, the anti-IBDV level was measured by an ELISA test.

All of the experimental data were subjected to statistical analysis by two-way analysis of variance.

\section{RESULTS}

Feeding chicks during $20 \mathrm{~h}$ of transportation did not significantly alter the broilers' body weight or the weight and chemical composition of yolk sacs (Table 1). It should be emphasised, however, that the weight of yolk sacs derived from $\mathrm{F}+$ chicks at the age of 24 and $72 \mathrm{~h}$ was lower by about $10 \%$.

In the yolk sacs sampled after $72 \mathrm{~h}$, a remarkable change in the FA profile was observed: in $\mathrm{F}+$ chickens, the share of SFA and PUFA was higher compared with F- chicks.

The anti-IBDV level was not significantly influenced by feeding chicks during transportation, however, it was lower in the group given prestarter. Morbidity and mortality were not influenced either.

* The feed formula used was Nutriful produced by Trouw Nutrition 
Table. 1. The effect of feeding chicks during transportation on broiler body weight, yolk sac weight, composition, and fatty acid profile, as well as blood anti-IBDV level

\begin{tabular}{|c|c|c|c|c|c|c|c|c|c|c|c|c|}
\hline \multirow{3}{*}{$\begin{array}{l}\text { Main } \\
\text { effects }\end{array}$} & \multicolumn{12}{|c|}{ Broiler age, $\mathrm{h}$} \\
\hline & & \multirow[t]{2}{*}{0} & \multicolumn{2}{|c|}{24} & \multicolumn{2}{|c|}{72} & \multicolumn{2}{|c|}{120} & \multicolumn{2}{|c|}{168} & \multicolumn{2}{|c|}{336} \\
\hline & & & $\mathrm{F}+$ & F- & $\mathrm{F}+$ & F- & $\mathrm{F}+$ & F- & $\mathrm{F}+$ & F- & $\mathrm{F}+$ & F- \\
\hline \multirow{4}{*}{$\begin{array}{l}\text { BW, } \\
\text { g } \\
\text { YSW, } \\
\text { g }\end{array}$} & $\mathrm{x}$ & 39.3 & 38.4 & 37.9 & 70.3 & 66.3 & 103 & 95 & 138 & 132 & 461 & 460 \\
\hline & \pm & 2.31 & 3.16 & 2.20 & 6.60 & 6.11 & 9.97 & 8.41 & 12.9 & 14.3 & 39 & 39 \\
\hline & $\mathrm{x}$ & 4.82 & 3.05 & 3.41 & 0.78 & 0.86 & 0.43 & & 0.18 & 0.15 & - & - \\
\hline & \pm & 0.69 & 0.85 & 0.67 & 0.30 & 0.37 & 0.31 & 0.24 & 0.16 & 0.12 & - & - \\
\hline \multirow{2}{*}{$\begin{array}{l}\text { YSP, } \\
\%\end{array}$} & $\mathrm{x}$ & 27.6 & 30.7 & 30.1 & 24.9 & 24.7 & 17.6 & 19.2 & 12.5 & 14.2 & - & - \\
\hline & \pm & 1.48 & & 1.45 & 0.32 & 0.41 & 1.11 & 0.93 & 2.01 & 1.07 & - & - \\
\hline \multirow{2}{*}{$\begin{array}{l}\text { YSF, } \\
\%\end{array}$} & $\mathrm{x}$ & 15.0 & 10.7 & 11.1 & 9.8 & 9.2 & 12.4 & 13.5 & - & - & - & - \\
\hline & \pm & 0.33 & & 0.74 & 0. & 0.72 & 0.22 & 0.24 & - & - & - & - \\
\hline \multirow{2}{*}{ SFA } & $\mathrm{x}$ & 35.6 & 32.1 & 32.8 & $32.9^{\mathrm{a}}$ & $28.5^{\mathrm{b}}$ & 34.2 & 32.1 & - & - & - & - \\
\hline & \pm & & & & & & 2.17 & & - & - & - & - \\
\hline \multirow{2}{*}{ MUFA } & $\mathrm{x}$ & 51.9 & 55.3 & 55.0 & $54.1^{\mathrm{a}}$ & $61.4^{\mathrm{b}}$ & 50.1 & 53.0 & - & - & - & - \\
\hline & \pm & 3.18 & 3.24 & 3.00 & & 3. & 3.10 & 2.95 & - & - & - & - \\
\hline \multirow{2}{*}{ PUFA } & $\mathrm{x}$ & 12.0 & 12.6 & 11.8 & $12.2^{\mathrm{a}}$ & $9.5^{\mathrm{b}}$ & 15.3 & 17.3 & - & - & - & - \\
\hline & \pm & 0.98 & 1.02 & 0.99 & 0.90 & 0.65 & 1.16 & 1.37 & - & - & - & - \\
\hline & & & & 3839 & 2777 & 3220 & 1912 & 2319 & 1368 & 1495 & 142 & 184 \\
\hline vel & & 112 & 1316 & 1207 & 998 & 1147 & 773 & 1359 & 756 & 982 & 130 & 102 \\
\hline
\end{tabular}

BW - body weight, YSW - yolk sac weight, YSP - yolk sac protein content, YSF - yolk sac fat content; means with different superscripts differ at $\mathrm{P} \leq 0.05$

\section{DISCUSSION}

In the early stages of raising, the chicks fed prestarter were slightly heavier (by $8 \%$ at the age of $72 \mathrm{~h}$ ), but on the last day of the experiment the differences had diminished, which confirms the earlier results by Pisarski et al. (1998) and these obtained by Wertelecki and Jamroz (2000) as well as Saki (2005).

The slightly lower weight of yolk sacs of the chicks given prestarter, determined at the age of 24 and $72 \mathrm{~h}$, seems to confirm the opinions on the dependence on yolk sac in early feeding (Pisarski et al., 1998; Noy and Sklan, 2001). This study did not show significant changes in yolk sac composition, however, it was found that the sacs obtained after $72 \mathrm{~h}$ of rearing from the chicks deprived of feed during transportation contained less fat (approx. 6.5\%) compared with the chicks given prestarter. It was demonstrated that in the period from 24 through $72 \mathrm{~h}$, F- chicks utilized more endogenous lipids than the F+ chicks. Considering the FA profile, one can suppose that in this period the F- chicks utilized SFA and PUFA to a higher extent than the F+ chicks. The anti-IBDV level determined throughout experiment confirmed the opinion on the rate of immunoglobulin transfer from the yolk to the blood stream (Szeleszczuk et al., 2001), however it did not show any benefit of early feeding on broiler immunity. 


\section{CONCLUSIONS}

Feeding chicks during transportation does not affect broiler body weight as well as the weight and chemical composition of yolk sac nor does it affect the anti-IBDV level.

The data obtained suggest that chicks do not have to be fed during transportation from the hatchery, however, further relevant studies should be undertaken to confirm these results.

\section{REFERENCES}

Cherian G., Sim J.S., 1997. Egg yolk polyunsaturated fatty acids and vitamin E content alters the tocopherol status of hatched chicks. Poultry Sci. 76, 1753-1759

Noy Y., Sklan D., 2001. Yolk and exogenous feed utilisation in the posthatch chick. Poultry Sci. 80, 1490-1495

Pisarski R.K., Malec L., Borzemska B.W., Malec H., 1998. The effect of the first feeding time of broiler chicks upon body weight, yolk sac absorption and some constituents of blood plasma (in Polish). Med. wet. 54, 607-611

Saki A.A., 2005. Effect of post-hatch feeding on broiler performance. Intern. J. Poultry Sci. 4, 4-6

Szeleszczuk P., Malec H., Pijarska I., Jank M., Niedziółka J., 2001. Maternal transfer of antibodies against IBDV, REOV, IBV and NDV in pre and postnatal period in commercial broilers. In: Proceedings of the Conference Cost Action. Immunosupresive Viral Diseases in Poultry. Puławy (Poland), p. 839

Vieira S.L., Moran E.T., 1999. Effects of delayed placement and used litter on broiler yields. J. Appl. Poultry Res. 8, 75-81

Wertelecki T., Jamroz D., 2000. The effect of fat level and the first feeding time on yolk sac absorption, pancreas activity changes and development of GIT in chickens (in Polish). Zesz. nauk. Prz. hod. 49, 387-397

\section{STRESZCZENIE}

\section{Wpływ karmienia piskląt podczas transportu na cechy woreczka żóltkowego, masę ciała i miano anty-IBDV u brojlerów}

Karmienie piskląt mieszanką prestarter podczas 20 godz. transportu z wylęgarni nie wpłynęło istotnie ani na masę ciała brojlerów odchowywanych do 14 dni, ani na masę i skład chemiczny woreczka żółtkowego. W lipidach woreczków żółtkowych pobranych po 3 dniach odchowu stwierdzono jednak istotne zróżnicowanie profilu kwasów tłuszczowych: w grupie piskląt karmionych udział SFA i PUFA był większy niż w grupie ptaków niekarmionych, zaś udział MUFA mniejszy. Podanie pisklętom mieszanki prestarter podczas transportu z wylęgarni nie wpłynęło istotnie na ich odporność wyrażoną mianem anty-IBDV. 